\title{
Vitamin D signaling increases nitric oxide and antioxidant defenses of bovine monocytes
}

\author{
Mercedes F. Kweh, ${ }^{1}$ Kathryn E. Merriman, ${ }^{1}$ Teri L. Wells, ${ }^{2}$ and Corwin D. Nelson ${ }^{2 *} \odot$
}

\section{Graphical Abstract}
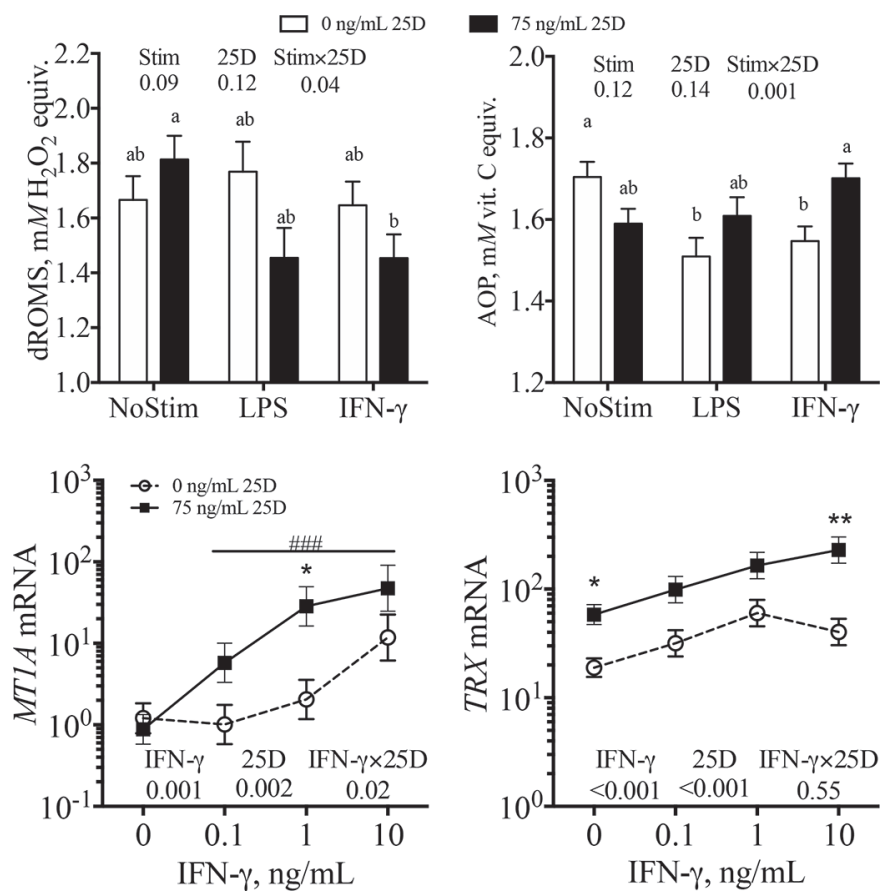

\section{Summary}

The oxidative burst of phagocytes is a key part of antimicrobial defenses. Vitamin D contributes to several aspects of bovine immunity, including antimicrobial activity. Our objectives were to assess the effects of vitamin $\mathrm{D}$ on the oxidant and antioxidant responses of freshly isolated monocytes of dairy cows. Vitamin D increased antioxidant potential of interferon- $\gamma$-stimulated monocyte cultures. Vitamin D also increased mRNA transcripts for metallothionein $(M T 1 A)$ and thioredoxin (TRX) genes. Our data indicate a potential role for vitamin D in maintaining redox balance during infection.

\section{Highlights}

- Vitamin D and interferon-gamma (IFN- - ) increased monocyte nitric oxide production

- IFN- $\gamma$ decreased antioxidant potential of monocyte cultures

- Vitamin D signaling increased antioxidant potential of IFN- $\gamma$-stimulated monocytes

- Vitamin D increased abundance of metallothionein and thioredoxin transcripts

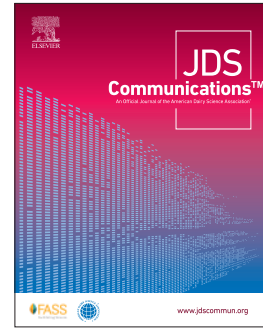

\footnotetext{
${ }^{1}$ Animal Molecular and Cellular Biology Graduate Program, University of Florida, Gainesville 32611, ${ }^{2}$ Department of Animal Sciences, University of Florida, Gainesville 32611. *Corresponding author: cdnelson@ufl.edu. @ 2021, The Authors. Published by Elsevier Inc. and Fass Inc. on behalf of the American Dairy Science Association ${ }^{\oplus}$. This is an open access article under the CC BY license (http://creativecommons.org/licenses/by/4.0/). Received July 07, 2020. Accepted November 24, 2020.
} 


\title{
Vitamin D signaling increases nitric oxide and antioxidant defenses of bovine monocytes
}

\author{
Mercedes F. Kweh, ${ }^{1}$ Kathryn E. Merriman, ${ }^{1}$ Teri L. Wells, ${ }^{2}$ and Corwin D. Nelson ${ }^{2 *} \odot$
}

\begin{abstract}
Vitamin D contributes to multiple aspects of bovine immunity and is reported to decrease the effects of mastitis and metritis in dairy cows. We hypothesized that vitamin D signaling in bovine monocytes increases antioxidant responses as part of its immunomodulatory actions. Our objectives were to assess the effects of vitamin D on oxidant and antioxidant responses of bovine monocytes. Monocytes from peripheral blood of nonpregnant, lactating Holstein cows between 90 and $300 \mathrm{~d}$ in milk were used for in vitro cell culture experiments. To test the effects of vitamin $\mathrm{D}$ on reactive oxygen metabolites (dROM) and antioxidant potential (AOP), monocytes from 14 cows were cultured in replicates for $16 \mathrm{~h}$ with 25 -hydroxyvitamin $\mathrm{D}_{3}\left[25(\mathrm{OH}) \mathrm{D}_{3}, 0\right.$ or $\left.75 \mathrm{ng} / \mathrm{mL}\right]$ in a factorial arrangement with lipopolysaccharide (LPS, $100 \mathrm{ng} / \mathrm{mL}$ ) or interferon- $\gamma(\mathrm{IFN}-\gamma, 10 \mathrm{ng} / \mathrm{mL})$ or with no stimulation. Data were analyzed by ANOVA for main effects of $25(\mathrm{OH}) \mathrm{D}_{3}$, stimulant, and interactions between $25(\mathrm{OH}) \mathrm{D}_{3}$ and stimulant. Significant interactions between $25(\mathrm{OH}) \mathrm{D}_{3}$ and stimulant were observed for $\mathrm{dROM}$ and $\mathrm{AOP}$ of culture supernatants. In unstimulated cultures, $25(\mathrm{OH}) \mathrm{D}_{3}$ tended to increase dROM, but the opposite was observed in stimulated cultures. In contrast, LPS and IFN- $\gamma$ treatments alone decreased AOP of culture supernatants, but $25(\mathrm{OH}) \mathrm{D}_{3}$ counteracted the decrease in AOP caused by IFN- $\gamma$. Abundances of transcripts of genes encoding antioxidant-related proteins were measured by quantitative PCR using RNA from monocytes from 4 cows treated with $25(\mathrm{OH}) \mathrm{D}_{3}(0 \mathrm{or} 75 \mathrm{ng} / \mathrm{mL})$ in a factorial arrangement with increasing concentrations of LPS $(0$ to $1,000 \mathrm{ng} / \mathrm{mL})$ or IFN- $\gamma(0$ to $10 \mathrm{ng} / \mathrm{mL})$. Treatment with $25(\mathrm{OH}) \mathrm{D}_{3}$ increased transcripts of genes encoding metallothionein $1 \mathrm{~A}$ and metallothionein $2 \mathrm{~A}$ in the presence of IFN- $\gamma$ but not LPS. Furthermore, $25(\mathrm{OH}) \mathrm{D}_{3}$ increased transcripts of genes encoding thioredoxin and thioredoxin reductase, but the effect of $25(\mathrm{OH}) \mathrm{D}_{3}$ did not depend on IFN- $\gamma$ or LPS stimulation. In conclusion, $25(\mathrm{OH}) \mathrm{D}_{3}$ increased antioxidant capacity of IFN- $\gamma$-stimulated bovine monocytes, potentially by increasing metallothionein and thioredoxin activities in monocytes.
\end{abstract}

$\mathbf{R}$

ecent reports have documented positive effects of 25-hydroxyvitamin $\mathrm{D}_{3}\left[\mathbf{2 5}(\mathbf{O H}) \mathbf{D}_{3}\right]$ for protection against uterine and mammary infections in dairy cows (Lippolis et al., 2011; Martinez et al., 2018; Poindexter et al., 2020). Concentrations of $25(\mathrm{OH}) \mathrm{D}_{3}$ in serum of dairy cows during the postpartum period, a time when cows are at greatest risk of disease, are lower compared with those during prepartum or mid lactation (Nelson et al., 2016; Holcombe et al., 2018). Moreover, Wisnieski et al. (2020) reported that cows with serum $25(\mathrm{OH}) \mathrm{D}_{3}>71 \mathrm{ng} / \mathrm{mL}$ in the postpartum period were at lowest risk for uterine diseases.

The direct actions of vitamin $\mathrm{D}$ in the immune system of cows provide a likely explanation for the positive effects of $25(\mathrm{OH}) \mathrm{D}_{3}$ in reduction of dairy cow diseases. Toll-like receptor agonists such as LPS and IFN- $\gamma$ stimulate an intracrine vitamin D pathway in innate immune cells that contributes to activation of multiple immune functions. For example, intramammary LPS challenge increased transcripts for $1 \alpha$-hydroxylase (CYP27B1), which catalyzes conversion of $25(\mathrm{OH}) \mathrm{D}_{3}$ to 1,25 -dihydroxyvitamin $\mathrm{D}_{3}\left[\mathbf{1 , 2 5}(\mathbf{O H})_{2} \mathbf{D}_{3}\right]$, and the vitamin D receptor (VDR) in macrophages and neutrophils in the mammary gland (Merriman et al., 2018). The effects of vitamin D signaling in immunity are quite diverse and include induction of antimicrobial responses and chemokines, and suppression of proinflammatory $\mathrm{T}$ cells and cytokines (Hewison, 2012). In particular, $1,25(\mathrm{OH})_{2} \mathrm{D}_{3}$ elicits a robust nitric oxide (NO) response in bovine monocytes and macrophages, which enhances killing of Mycobacteria bovis by macrophages (García-Barragán et al., 2018). Intramammary and dietary vitamin D treatments also increased abundance of transcripts for inducible nitric oxide synthase (NOS2) in immune cells of the mammary glands of cows (Merriman et al., 2017; Poindexter et al., 2020). However, NO production by immune cells may increase oxidation of host cell membranes and proteins and, if not balanced by protective antioxidant mechanisms, lead to tissue damage (Shi et al., 2018). In addition to the effects of vitamin D on nitric oxide, it also is known to have positive effects on antioxidant status in human and rodent cells. We hypothesized that vitamin D signaling in bovine monocytes would increase antioxidant responses to counteract pro-oxidant responses to LPS or IFN- $\gamma$. Therefore, our objectives were to assess the effects of vitamin D signaling on oxidant and antioxidant responses of bovine monocytes.

Monocytes used in the experiments were collected from lactating, nonpregnant Holstein cows at the University of Florida Dairy Unit according to approval of the University of Florida Institutional Animal Care and Use Committee. Average \pm SD parity, days in milk, and milk yield of cows were $1.7 \pm 0.9$ parities, $207 \pm 99 \mathrm{~d}$, and $29.5 \pm 9.4 \mathrm{~kg} / \mathrm{d}$, respectively. Cows were free of any clinical diseases before and at the time of blood collection. Cows were fed a standard lactating cow TMR that provided cows with approximately $40,000 \mathrm{IU}$ of vitamin $\mathrm{D}_{3} / \mathrm{d}$.

Monocytes were isolated as previously described (Merriman et al., 2015). Briefly, $50 \mathrm{~mL}$ of blood was sampled from the jugular vein using $60-\mathrm{mL}$ syringes containing $5 \mathrm{~mL}$ of acid citric dextrose

\footnotetext{
Animal Molecular and Cellular Biology Graduate Program, University of Florida, Gainesville $32611,{ }^{2}$ Department of Animal Sciences, University of Florida, Gainesville 32611. *Corresponding author: cdnelson@ufl.edu. @ 2021, The Authors. Published by Elsevier Inc. and Fass Inc. on behalf of the American Dairy Science Association ${ }^{\oplus}$. This is an open access article under the CC BY license (http://creativecommons.org/licenses/by/4.0/). Received July 07, 2020. Accepted November 24, 2020.
} 
solution. Blood was centrifuged at $1,500 \times g$ for $20 \mathrm{~min}$, the buffy coat layer was collected, and erythrocytes were removed by hypotonic lysis. Mononuclear cells were then layered over $1.083 \mathrm{~g} /$ $\mathrm{mL}$ Percoll and centrifuged for $30 \mathrm{~min}$ at $450 \times g$ to remove any remaining neutrophils. Monocytes were isolated by adherence on a T-75 tissue-culture-treated flask for $1 \mathrm{~h}$ in RPMI 1640 medium (Hyclone Laboratories, Logan UT) containing 10\% fetal bovine serum (characterized; Hyclone Laboratories). After removal of non-adherent cells by washing with warm Dulbecco's PBS, monocytes were collected from the flask with ice-cold PBS. Monocytes were counted, resuspended in RPMI 1640 medium containing penicillin-streptomycin (100 units each $/ \mathrm{mL})$ and $10 \%$ fetal bovine serum to a concentration of $1 \times 10^{6}$ cells $/ \mathrm{mL}$. Finally, $200 \mu \mathrm{L}$ of cell suspensions were added to 96 -well tissue culture-treated plates before applying treatments. All cell culture reagents, unless otherwise noted, were purchased from Fisher Scientific (Waltham, $\mathrm{MA})$. The $25(\mathrm{OH}) \mathrm{D}_{3}$ and 1,25-dihydroxyvitamin $\mathrm{D}_{3}$ were purchased from Cayman Chemical (Ann Arbor, MI) and dissolved in reagent-grade ethanol. Lipopolysaccharide derived from Serratia marcescens was purchased from Sigma Aldrich (St. Louis, MO). Recombinant bovine IFN- $\gamma$ was purchased from R\&D Systems (Minneapolis, MN).

Each experiment was a randomized, complete block design with cow (the source of monocytes) as the blocking factor. For experiments used to test effects of $25(\mathrm{OH}) \mathrm{D}_{3}$ on nitrite (experiment 1 ), reactive oxygen metabolites and antioxidant potential (experiment 2), 2 levels of $25(\mathrm{OH}) \mathrm{D}_{3}(0$ or $75 \mathrm{ng} / \mathrm{mL})$ and 3 types of stimula-

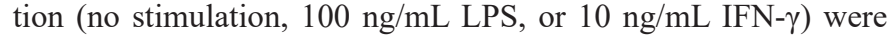
applied in a factorial arrangement. Experiment 1 was replicated with monocytes from 7 cows, whereas experiment 2 was replicated with monocytes from 14 cows. Experiment 3 tested the effects of $1,25(\mathrm{OH})_{2} \mathrm{D}_{3}$ on monocyte gene expression. Monocytes from 4 cows were stimulated with 0 or $100 \mathrm{ng} / \mathrm{mL}$ LPS and 0 or $4 \mathrm{ng} / \mathrm{mL}$ of $1,25(\mathrm{OH})_{2} \mathrm{D}_{3}$ in a factorial arrangement. Experiment 4 tested the effect of $25(\mathrm{OH}) \mathrm{D}_{3}$ in combination with LPS or IFN- $\gamma$. Monocytes from 4 cows were treated with $25(\mathrm{OH}) \mathrm{D}_{3}$ at 0 or $75 \mathrm{ng} / \mathrm{mL}$ in a factorial arrangement with 4 levels of LPS $(0,10,100$, and 1,000 $\mathrm{ng} / \mathrm{mL})$ or IFN- $\gamma(0,0.1,1$, and $10 \mathrm{ng} / \mathrm{mL})$. For each experiment, monocyte cultures were incubated for $16 \mathrm{~h}$ in a humidified $\mathrm{CO}_{2}$ incubator at $37^{\circ} \mathrm{C}$ with $5 \% \mathrm{CO}_{2}$.

Concentrations of nitrite in cell culture supernatants were measured using the Griess assay ( $0.5 \%$ sulfanilamide, $2.5 \%$ phosphoric acid, and $0.05 \% \mathrm{~N}$-naphthyl-ethylenediamine dihydrochloride; Sigma) as previously described (Nelson et al., 2010). Nitrite is generated from NO in aerobic aqueous solutions, whereas, peroxynitrite is generated from reaction of NO with superoxides in diffusion-limited environments (Ignarro et al., 1993). Concentrations of reactive oxygen metabolites (dROM) and antioxidant potential (AOP) of cell culture supernatants were measured using the FRAS-5 system with Redox Fast kits (H\&D S.R.L. Str. Langhirano, Parma, Italy) according to the manufacturer's instructions. The assays were performed immediately after collection of culture supernatants. The dROM assay measures hydroperoxides by photometric measurement of oxidized diethyl-para-phenylenediamine (DEPPD) absorption at $505 \mathrm{~nm}$. The dROM assay is not known to distinguish between reactive nitrogen species (RNS) and reactive oxygen species (ROS) derivatives (Alberti et al., 2000). Briefly, $10 \mu \mathrm{L}$ of culture supernatant was added to the dROM kit reagent containing DEPPD, mixed gently for $10 \mathrm{~s}$, and measured with the FRAS-5 photometer. Likewise, the AOP assay measures capacity to reduce ferric iron in the sample by photometric absorption at 505 $\mathrm{nm}$. Ten microliters of supernatant was added to the AOP reagent, mixed gently for $10 \mathrm{~s}$, and measured with the FRAS-5 photometer. The dROM and AOP are reported in equivalents of $\mathrm{H}_{2} \mathrm{O}_{2}$ and ascorbic acid, respectively.

The oxidative burst capacity of monocytes was measured using dihydrorhodamine 123 (DHR, Sigma). Reactive nitrogen species (i.e., peroxynitrite) and ROS, but not NO, will oxidize DHR to rhodamine (Crow, 1997). After culture with treatments for $16 \mathrm{~h}$, monocytes were removed from the cell culture plate, resuspended in $100 \mu \mathrm{L}$ of fresh culture medium, and incubated with $10 \mu \mathrm{L}$ of 50 $\mu M$ DHR for $10 \mathrm{~min}$ at $37^{\circ} \mathrm{C}$. Eight million colony-forming units of heat-killed Escherichia coli O8:H19, prepared as previously described (Martinez et al., 2018), was then added to monocytes, resulting in $40 \mathrm{E}$. coli per monocyte to stimulate oxidative burst in monocytes. Samples incubated for $30 \mathrm{~min}$ at $37^{\circ} \mathrm{C}$ with continuous mixing were then analyzed using an Accuri C6 flow cytometer (Becton Dickinson). Median fluorescence intensities (MFI) of DHR in 2,500 cells were determined with FCS Express 6.0 (De Novo Software, Pasadena, CA).

Total RNA of monocytes was isolated using the Quick-RNA MiniPrep RNA isolation kit (Zymo Research, Irvine, CA) as per the manufacturer's instructions and eluted with $80 \mu \mathrm{L}$ of nucleasefree water. The RNA $(10 \mu \mathrm{L}$ at $9 \pm 5 \mathrm{ng} / \mu \mathrm{L}, 260 / 280$ ratio of 1.8 \pm 0.3 ) was reverse transcribed using the High Capacity cDNA Reverse Transcription Kit (Life Technologies, Carlsbad, CA) in a $20-\mu \mathrm{L}$ reaction as per the manufacturer's instructions with random primers and $1 \mu \mathrm{L}$ of RNase inhibitor (RiboLock, Thermo Fisher Scientific, Waltham, MA). The reverse transcription reaction was incubated in a thermal cycler (Eppendorf, Hamburg, Germany) for $10 \mathrm{~min}$ at $25^{\circ} \mathrm{C}, 60 \mathrm{~min}$ at $37^{\circ} \mathrm{C}$, and $5 \mathrm{~min}$ at $85^{\circ} \mathrm{C}$. Quantitative PCR was performed as previously described (Kweh et al., 2019) using a CFX96 Touch Real-Time PCR Detection System (BioRad, Hercules, CA) with $20-\mu \mathrm{L}$ reactions containing $9 \mu \mathrm{L}$ of cDNA, 0.5 $\mu \mathrm{L}$ each of forward and reverse primers, and $10 \mu \mathrm{L}$ of SYBR Select qPCR Master Mix (ThermoFisher). Primer sequences for $\beta$-actin $(A C T B), G A P D H$, ribosomal protein S9 (RPS9), $1 \alpha$-hydroxylase (CYP27B1), 24-hydroxylase (CYP24A1), $\beta$-defensin 7 (DEFB7), inducible nitric oxide synthase (NOS2), glutathione peroxidase 1 $(G P X 1)$, metallothionein 1A (MT1A), metallothionein 2A (MT2A), nuclear factor erythroid 2-related factor 2 (NFE2L2), thioredoxin $(T R X)$, and thioredoxin reductase 1 (TXNRD1) genes are provided in Table 1. The threshold cycle $(\mathbf{C t})$ for each gene was normalized to the geometric mean of $A C T B, G A P D H$, and RPS9 Ct values using the equation $\Delta \mathrm{Ct}=\mathrm{Ct}_{\text {(target gene) }}-\mathrm{Ct}_{\text {(reference genes) }}$. The $\Delta \mathrm{Ct}$ values for each gene were used for statistical analysis.

Data were analyzed by ANOVA using the GLIMMIX procedure in SAS (version 9.4, SAS Institute Inc., Cary, NC). Residuals were observed for normal distribution. The general mathematical model used for the analysis was $Y_{i j k}=\mu+B_{i}+L_{j}+D_{k}+L_{j} D_{k}+e_{i j k}$, where $Y_{i j k}=$ dependent variable, $\mu=$ overall mean, $B_{i}=$ fixed effect of cow that was source of cells, $L_{j}=$ fixed effect of stimulant or dose of stimulant, $\mathrm{D}_{\mathrm{k}}=$ fixed effect of vitamin $\mathrm{D}$, and $\mathrm{e}_{\mathrm{ijk}}=$ residual error. For experiments 1 and 2, main effects of 25(OH) $\mathrm{D}_{3}(0$ vs. $75 \mathrm{ng} / \mathrm{mL}$ ), stimulant (no stimulant, LPS or IFN- $\gamma$ ), and interaction between stimulant and $25(\mathrm{OH}) \mathrm{D}_{3}$ were analyzed. 
The model for experiment 3 included effects of LPS ( 0 vs. 100 $\mathrm{ng} / \mathrm{mL}), 1,25(\mathrm{OH})_{2} \mathrm{D}_{3}(0 \mathrm{vs} .4 \mathrm{ng} / \mathrm{mL})$, interaction between LPS and $1,25(\mathrm{OH})_{2} \mathrm{D}_{3}$, and cow. Experiment 4 was performed as one experiment, but the effects of $25(\mathrm{OH}) \mathrm{D}_{3}$ were analyzed separately for LPS and IFN- $\gamma$ treatments to account for the multiple doses of LPS and IFN- $\gamma$ that were used. The model used for experiment 4 included effects of $25(\mathrm{OH}) \mathrm{D}_{3}(0 \mathrm{vs} .75 \mathrm{ng} / \mathrm{mL})$, dose of stimulant ( 0 to $10 \mathrm{ng} / \mathrm{mL} \mathrm{IFN-} \gamma$ or 0 to $1,000 \mathrm{ng} / \mathrm{mL} \mathrm{LPS}$ ), and interaction between $25(\mathrm{OH}) \mathrm{D}_{3}$ and dose of stimulant. Furthermore, the contrast statement was used to test the effect of $25(\mathrm{OH}) \mathrm{D}_{3}$ in the presence of stimulant (IFN- $\gamma$ at $0.1,1$ and $10 \mathrm{ng} / \mathrm{mL}$; LPS at 10, 100 and $1,000 \mathrm{ng} / \mathrm{mL}$ ). Least squares means were computed for the interactions of $25(\mathrm{OH}) \mathrm{D}_{3}$ with LPS and IFN- $\gamma$, and the Tukey adjustment was applied to account for multiple comparisons of means. For gene expression data, least squares means of $\Delta \mathrm{Ct}$ values were transformed using the equation $\left(2^{-\Delta \mathrm{Ct}}\right)$ and expressed as relative number of transcripts. Statistical significance was declared at $P<$ 0.05 and tendencies were declared at $P<0.10$ and $P>0.05$.

Treatment of monocytes with IFN- $\gamma$, LPS, and $25(\mathrm{OH}) \mathrm{D}_{3}$ increased $(P<0.01)$ nitrite concentrations in culture supernatants (Figure 1A). However, none of the factors (LPS, IFN- $\gamma$, or $25(\mathrm{OH})$ $\mathrm{D}_{3}$ ) alone increased nitrite compared with cultures not stimulated and not treated with $25(\mathrm{OH}) \mathrm{D}_{3}$. Rather, nitrite was greater $(P<$ $0.05)$ in cultures treated with LPS and $25(\mathrm{OH}) \mathrm{D}_{3}$ or IFN- $\gamma$ and $25(\mathrm{OH}) \mathrm{D}_{3}$ compared with cultures that did not receive stimulant or $25(\mathrm{OH}) \mathrm{D}_{3}$ (Figure 1A). The IFN- $\gamma$ treatment increased oxidative burst capacity, as measured by DHR in response to heat-killed $E$. coli challenge, but LPS and $25(\mathrm{OH}) \mathrm{D}_{3}$ treatments did not affect oxidative burst capacity of monocytes (Figure 1B). Interactions were observed between $25(\mathrm{OH}) \mathrm{D}_{3}$ and stimulation for dROM $(P$ $=0.04)$ and AOP $(P=0.001)$. In the absence of LPS or IFN- $\gamma$, $25(\mathrm{OH}) \mathrm{D}_{3}$ tended to increase $\mathrm{dROM}$ in culture supernatants but had the opposite effect in the presence of LPS or IFN- $\gamma$ stimulation such that dROM was lower $(P<0.05)$ in cultures treated with $25(\mathrm{OH}) \mathrm{D}_{3}$ and IFN- $\gamma$ compared with $25(\mathrm{OH}) \mathrm{D}_{3}$ alone (Figure $1 \mathrm{C}$ ). In contrast, $25(\mathrm{OH}) \mathrm{D}_{3}$ somewhat decreased AOP in the absence of IFN- $\gamma$ or LPS but counteracted the decrease in AOP caused by stimulation, such that AOP of cultures treated with IFN- $\gamma$ and $25(\mathrm{OH}) \mathrm{D}_{3}$ was greater $(P=0.04)$ than AOP of cultures treated with IFN- $\gamma$ alone (Figure 1D).

We also evaluated the effects of vitamin D signaling on expression of antioxidant genes that may explain the changes in antioxidant potential of monocytes. Metallothionein and thioredoxin genes were increased by $1,25(\mathrm{OH})_{2} \mathrm{D}_{3}$ treatment according to RNA sequencing of monocytes treated with $1,25(\mathrm{OH})_{2} \mathrm{D}_{3}$ and LPS $(\mathrm{C}$. D. Nelson, University of Florida, and J. D. Lippolis, USDA-ARS National Animal Disease Center, Ames, IA; unpublished data). Therefore, we hypothesized that vitamin D may increase expression of antioxidant genes in bovine monocytes. Because $1,25(\mathrm{OH})_{2} \mathrm{D}_{3}$ has more potent activity than $25(\mathrm{OH}) \mathrm{D}_{3}$ and it does not depend on CYP27B1 activity, the effects of vitamin D on expression of several genes encoding for antioxidant proteins were assessed in monocyte cultures treated with LPS and $1,25(\mathrm{OH})_{2} \mathrm{D}_{3}$ (Table 1). We found that $1,25(\mathrm{OH})_{2} \mathrm{D}_{3}$ increased, or tended to increase, transcripts of GPX1, MT1A, MT2A, TRX, and TXNRD1 genes but not transcripts of $N F E 2 L 2$. As positive controls of $1,25(\mathrm{OH})_{2} \mathrm{D}_{3}$ activity, $1,25(\mathrm{OH})_{2} \mathrm{D}_{3}$ also increased $C Y P 24 A 1, D E F B 7$, and $N O S 2$ expression, as previously reported (Merriman et al., 2015).

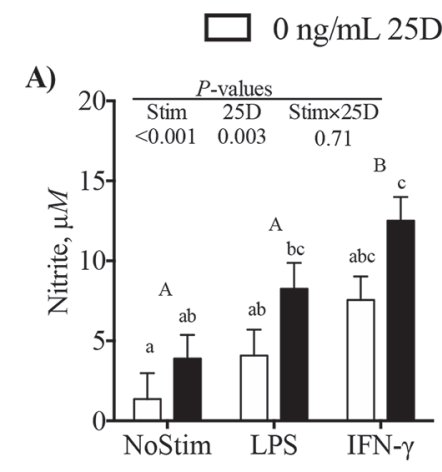

$75 \mathrm{ng} / \mathrm{mL} 25 \mathrm{D}$
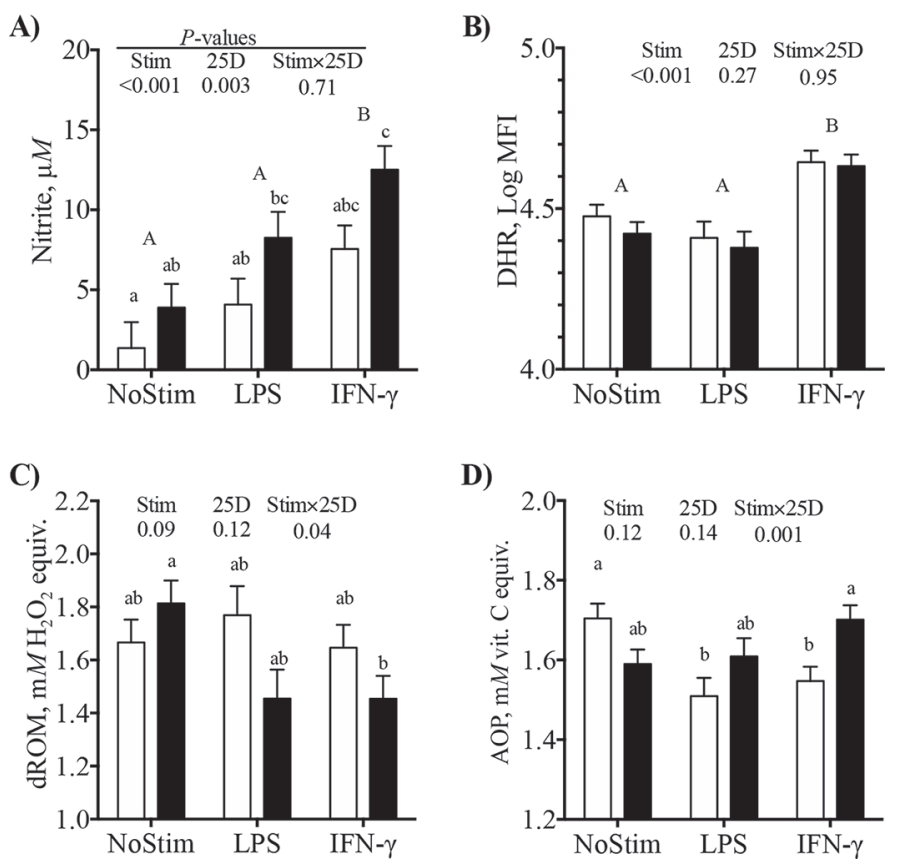

Figure 1. Monocytes from Holstein cows were treated with 0 or $75 \mathrm{ng} / \mathrm{mL}$ 25-hydroxyvitamin $\mathrm{D}_{3}$ (25D) in a factorial arrangement with no stimulant, $100 \mathrm{ng} / \mathrm{mL}$ LPS, or $10 \mathrm{ng} / \mathrm{mL}$ IFN- $\gamma$ for $16 \mathrm{~h}$. (A) Concentrations of nitrite in culture supernatant were measured using the Griess assay, $n=7$. (B) Median fluorescence intensity (MFI) of monocyte oxidative burst capacity as measured by oxidation of dihydrorhodamine (DHR) using flow cytometry. After a 16-h culture period with treatments, DHR was added and oxidative burst was stimulated by addition of heat-killed Escherichia coli; $\mathrm{n}=11$. (C, D) Supernatants were collected and assessed for reactive oxygen metabolites $(\mathrm{dROM})$ and antioxidant potential (AOP), $\mathrm{n}=14$. Values for $\mathrm{dROM}$ and $A O P$ are reported as $\mathrm{H}_{2} \mathrm{O}_{2}$ and vitamin $\mathrm{C}$ equivalents, respectively. For all plots, data represent $L S M \pm S E M$. The $P$-values for main effects of stimulant (IFN- $\gamma$, LPS or no stimulant), 25D ( 0 or $75 \mathrm{ng} / \mathrm{mL}$ ), and their interaction (Stim $\times 25 \mathrm{D}$ ) are indicated on each plot. The Tukey adjustment was applied to account for multiple means comparisons. Uppercase letters $(A, B)$ indicate that LSM for main effect of stimulant are different $(P<0.05)$, and lowercase letters $(a-c)$ indicate that LSM of individual treatments are different $(P<0.05)$.

To further characterize the role of vitamin D signaling on antioxidant response, the effects of $25(\mathrm{OH}) \mathrm{D}_{3}$ on expression of known vitamin D pathway and antioxidant genes were assessed (Figure 2). As previously reported, LPS increased CYP27B1 expression in monocyte cultures (Figure 2A). Likewise, IFN- $\gamma$ induced CYP27B1 in a dose-dependent manner (Figure 2A). CYP27B1 encodes $1 \alpha$-hydroxylase, which catalyzes conversion of $25(\mathrm{OH})$ $\mathrm{D}_{3}$ to $1,25(\mathrm{OH})_{2} \mathrm{D}_{3}$, indicating the potential for monocytes to increase $1,25(\mathrm{OH})_{2} \mathrm{D}_{3}$ synthesis when stimulated by IFN- $\gamma$ or LPS. In contrast, $25(\mathrm{OH}) \mathrm{D}_{3}$ increased $(P<0.001) C Y P 24 A 1$, which encodes the 24-hydroxylase that catalyzes inactivation of vitamin D (Figure 2B). Notably, IFN- $\gamma$ and LPS decreased CYP24A1 in the presence of $25(\mathrm{OH}) \mathrm{D}_{3}$ [IFN $-\gamma$ dose $\times 25(\mathrm{OH}) \mathrm{D}_{3}, P=0.006$; LPS dose $\times 25(\mathrm{OH}) \mathrm{D}_{3}, P=0.004$; Figure $2 \mathrm{~B}$ ]. Further demonstrating vitamin $\mathrm{D}$ pathway activity, transcripts of $D E F B 7$ and NOS2 were increased $(P<0.001)$ by $25(\mathrm{OH}) \mathrm{D}_{3}$ in the presence and absence 
Table 1. Effects of 1,25-dihydroxyvitamin $D_{3}$ on expression of antioxidant genes

\begin{tabular}{|c|c|c|c|}
\hline Gene & Primer sequence ${ }^{1}$ & Fold change ${ }^{2}$ & $P$-value ${ }^{3}$ \\
\hline$A C T B$ & $\begin{array}{l}\text { GGCATCCTGACCCTCAAGTA } \\
\text { CACACGGAGCTCGTTGTAGA }\end{array}$ & - & - \\
\hline GAPDH & $\begin{array}{l}\text { CCTGCCCGTTCGACAGATAG } \\
\text { ATGGCGACGATGTCCACTTT }\end{array}$ & - & - \\
\hline RPS9 & $\begin{array}{l}\text { GTGAGGTCTGGAGGGTCAAA } \\
\text { GGGCATTACCTTCGAACAGA }\end{array}$ & - & - \\
\hline CYP24A1 & $\begin{array}{l}\text { GAAGACTGGCAGAGGGTCAG } \\
\text { CAGCCAAGACCTCGTTGATT }\end{array}$ & 13.9 & $<0.01$ \\
\hline$C Y P 27 B 1$ & $\begin{array}{l}\text { TGGGACCAGATGTRRGCATTCGC } \\
\text { TTCTCAGACTGGTTCCTCATGGCT }\end{array}$ & 0.7 & 0.04 \\
\hline DEFB7 & $\begin{array}{l}\text { TCTTCCTGGTCCTGTCTGCT } \\
\text { GGTGCCAATCTGTCTCCTGT }\end{array}$ & 9.2 & $<0.01$ \\
\hline GPX1 & $\begin{array}{l}\text { GCAACCAGTTTGGGCATCAG } \\
\text { TAGGGTCGGTCATGAGAGCA }\end{array}$ & 1.8 & 0.02 \\
\hline MT1A & $\begin{array}{l}\text { TCCCATCCGACCAGTGGATCT } \\
\text { TTCTTGCAGGAGGGACATCTG }\end{array}$ & 1.8 & 0.06 \\
\hline MT2A & $\begin{array}{l}\text { GCCATCCTTTGCTCAGCAGT } \\
\text { GAGGCGCACTTGCAATCTTT }\end{array}$ & 1.6 & 0.04 \\
\hline NOS2 & $\begin{array}{l}\text { GATCCAGTGGTCGAACCTGC } \\
\text { CAGTGATGGCCGACCTGATG }\end{array}$ & 9.9 & $<0.01$ \\
\hline NFE2L2 & $\begin{array}{l}\text { GCATGATGGACTTGGAGCTG } \\
\text { GCTCATGCTCCTTCTGTCGT }\end{array}$ & 0.9 & 0.44 \\
\hline $\operatorname{TRX}$ & $\begin{array}{l}\text { ATTCCAACGTGGTGTTCCTTG } \\
\text { AGGTTGGCATGCATTTGACTT }\end{array}$ & 1.7 & $<0.01$ \\
\hline TXNRD1 & $\begin{array}{l}\text { AGGTCAAGCCCTACGAGACT } \\
\text { GCCCCAGTTGAGAGAACCAA }\end{array}$ & 1.8 & $<0.01$ \\
\hline
\end{tabular}

\footnotetext{
${ }^{1}$ Primer specificity and efficiency determined as previously described (Nelson et al., 2010). All primer pair efficiencies were $>95 \%$. Forward primer, top row; reverse primer, bottom row.

${ }^{2}$ Monocytes were treated with 0 or $100 \mathrm{ng} / \mathrm{mL} \mathrm{LPS}$ and 0 or $4 \mathrm{ng} / \mathrm{mL} 1,25$-dihydroxyvitamin $\mathrm{D}_{3}\left[1,25(\mathrm{OH})_{2} \mathrm{D}_{3}\right]$ in a factorial arrangement $\left(n=4\right.$ cows). Fold change represents main effect of $1,25(\mathrm{OH})_{2} \mathrm{D}_{3}$ compared with no $1,25(\mathrm{OH})_{2} \mathrm{D}_{3}$.

${ }^{3}$ Significance of the main effect of 1,25-dihydroxyvitamin $D_{3}$ treatment. LPS increased $(P<0.05)$ CYP27B1, MT1A, MT2A, NOS2, TRX, and TXNRD1. Interactions between LPS and 1,25(OH) $)_{2}(P<0.05)$ were observed for CYP24A1 and TXNRD1 but not the other genes.
}

of LPS or IFN- $\gamma$ (Figure $2 \mathrm{C}, \mathrm{D})$. However, IFN- $\gamma$ decreased $(P$ $<0.001) D E F B 7$ in a dose-dependent manner (Figure 2C), even though it strongly increased NOS2 expression (Figure 2D).

Although $1,25(\mathrm{OH})_{2} \mathrm{D}_{3}$ did not affect NF2EL2 expression in our other experiment (Table 1), we found that $25(\mathrm{OH}) \mathrm{D}_{3}$ decreased $(P<0.001) N F E 2 L 2$ expression (Figure 2E). In contrast, IFN- $\gamma$, but not LPS, increased NFE2L2 in a dose-dependent manner, and the suppression of $N F E 2 L 2$ by $25(\mathrm{OH}) \mathrm{D}_{3}$ dissipated as IFN- $\gamma$ increased (Figure 2E). Also, in contrast to our experiment with $1,25(\mathrm{OH})_{2} \mathrm{D}_{3}$, expression of $G P X 1$ was not affected by $25(\mathrm{OH}) \mathrm{D}_{3}$ in the presence of IFN- $\gamma$ and was decreased $(P=0.02)$ by $25(\mathrm{OH})$ $\mathrm{D}_{3}$ in the presence of LPS (Figure $2 \mathrm{~F}$ ).

The metallothionein genes $M T 1 A$ and $M T 2 A$ were increased by $25(\mathrm{OH}) \mathrm{D}_{3}$ but the effect of $25(\mathrm{OH}) \mathrm{D}_{3}$ depended on stimulation (Figure 2G, H). Transcripts of each gene were strongly increased $(P<0.01)$ by IFN- $\gamma$ or LPS stimulation. In the absence of stimulation, $25(\mathrm{OH}) \mathrm{D}$ did not affect $M T 1 A$ or $M T 2 A$; however, $25(\mathrm{OH}) \mathrm{D}_{3}$ increased $M T 1 A$ and $M T 2 A$ in the presence of IFN- $\gamma$ but not LPS stimulation [IFN- $\gamma \times 25(\mathrm{OH}) \mathrm{D}_{3}$ interaction, $P<0.05$ ].

Transcripts of TRX were generally increased 3-fold $(P<0.001)$ by $25(\mathrm{OH}) \mathrm{D}_{3}$, and the effect of $25(\mathrm{OH}) \mathrm{D}_{3}$ did not depend on IFN- $\gamma$ or LPS stimulation (Figure 2I). Stimulation with IFN- $\gamma$ also increased TRX expression in a dose-dependent manner $(P<$ $0.001)$, but LPS did not affect $T R X$ expression. Likewise, $25(\mathrm{OH})$ $\mathrm{D}_{3}$ increased TXNRD1 expression approximately 2-fold (Figure $2 \mathrm{~J})$. Both IFN- $\gamma$ and LPS increased TXNRD1 expression, and the effect of $25(\mathrm{OH}) \mathrm{D}_{3}$ appeared to become greater as the dose of LPS increased; however, the interactions between $25(\mathrm{OH}) \mathrm{D}_{3}$ and IFN- $\gamma$ or LPS were not significant.

Our data collectively show a role for vitamin D in maintaining the redox balance of bovine monocytes. The oxidative environment generated by production of superoxides and nitric oxide in phagocytes is a key element in elimination of bacterial pathogens and redox signaling (Weiss and Schaible, 2015). Indeed, GarcíaBarragán et al. (2018) reported that vitamin D-mediated NO production improved killing of Mycobacterium bovis. Generation of RNS, however, can lead to damage or impairment of infected tissues if not balanced by adequate supply of antioxidants (Trigona et al., 2006; Shi et al., 2018). As such, nutrients that have antioxidant properties or support antioxidant systems (i.e., vitamin E, Se, and $\mathrm{Cu}$ ) are key nutrients in protection of cattle from bacterial diseases (Sordillo, 2016). Here, our data indicate that vitamin D also supports antioxidant activity in monocytes via increasing thioredoxin and metallothionein systems.

Physiological systems use several antioxidant mechanisms to combat the ROS produced from normal metabolism or oxidative bursts of phagocytes (Virág et al., 2019). Endogenous antioxidants such as the glutathione, metallothionein, and thioredoxin systems are known to protect host cells from ROS and maintain the redox balance (Itoh et al., 2005; Trigona et al., 2006). Previous work showed that $1,25(\mathrm{OH})_{2} \mathrm{D}_{3}$ increased thioredoxin reductase gene expression and enzyme activity in the human THP-1 monocyte cell 
- $0 \mathrm{ng} / \mathrm{mL} 25 \mathrm{D}$

$\rightarrow 75 \mathrm{ng} / \mathrm{mL} 25 \mathrm{D}$
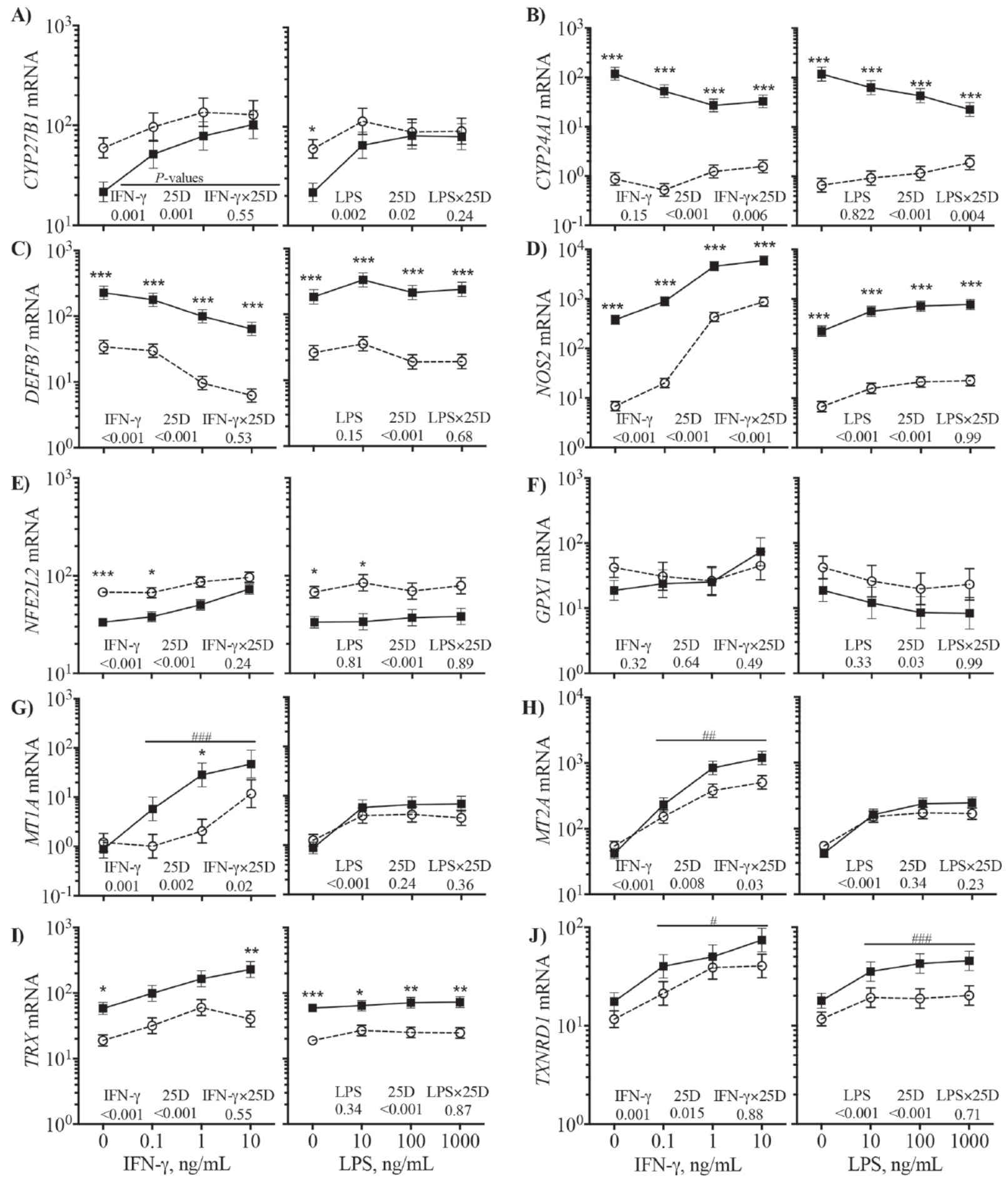

Figure 2. Monocytes from lactating Holstein cows $(n=4)$ were treated for $16 \mathrm{~h}$ with increasing concentrations of $\mathrm{LPS}$ or interferon- $\gamma($ IFN- $\gamma)$ with 0 or $75 \mathrm{ng} / \mathrm{mL}$ 25-hydroxyvitamin $\mathrm{D}_{3}(25 \mathrm{D})$ in a factorial arrangement. Transcripts for CYP27B1 (A), CYP24A1 (B), DEFB7 (C), NOS2 (D), NFE2L2 (E), GPX1 (F), MT1A (G), MT2A (H), TRX (I), and TXNRD1 (J) were measured by quantitative PCR. Data represent the LSM \pm SEM of $\triangle C t$ transformed by $2^{-\Delta C t}$ and expressed as abundance relative to reference genes. The $P$-values for main effects of stimulant dose (IFN- $\gamma, 0$ to $10 \mathrm{ng} / \mathrm{mL} ; \mathrm{LPS}, 0$ to $1,000 \mathrm{ng} / \mathrm{mL}), 25 \mathrm{D}(0 \mathrm{vs}$. $75 \mathrm{ng} / \mathrm{mL}$ ), and their interaction $\left(\mathrm{IFN}-\gamma \times 25 \mathrm{D}\right.$ or LPS $\times 25 \mathrm{D}$ ) are indicated on each plot. Tukey adjustment was made to account for multiple means comparison. ${ }^{*} P<0.05,{ }^{* *} P<0.01,{ }^{* * *} P<$ 0.001: effect of $25(\mathrm{OH}) \mathrm{D}_{3}$ within dose of stimulant is significant. $\# P<0.05$, \#\#P<0.01, \#\#\#P<0.001: effect of 25(OH) $\mathrm{D}_{3}$ in stimulated cultures $(0.1,1$, and 10 ng/ $\mathrm{mL}$ IFN- $\mathrm{y}$ or 10,100 , and $1,000 \mathrm{ng} / \mathrm{mL}$ LPS) is significant. 
line (Schütze et al., 1999). We hypothesized that vitamin D would increase antioxidant responses of bovine monocytes to counteract the pro-oxidant environment induced by TLR and IFN- $\gamma$ signaling. Collectively, our data show that vitamin D signaling contributes to induction of endogenous antioxidant systems of bovine monocytes. For example, in the presence of IFN- $\gamma$ stimulation, $25(\mathrm{OH})$ $\mathrm{D}_{3}$ increased antioxidant potential and expression of metallothionein genes. Furthermore, $25(\mathrm{OH}) \mathrm{D}_{3}$ increased expression of $T R X$ and TXNRD1 regardless of stimulation. Thioredoxin and metallothionein have protective roles against $\mathrm{NO}$-induced cell damage (Schwarz et al., 1995; Ferret et al., 2000). Thus, we speculate that increased antioxidant activity from thioredoxin and metallothionein may serve as a protective factor against vitamin $\mathrm{D}$-induced NO production in monocytes.

Certainly, our data do not rule out other antioxidant systems because we did not measure specific antioxidant activities. Glutathione peroxidase activity protects against nitric oxide-induced damage of mammary epithelial cells (Shi et al., 2018) and, in other species, vitamin D signaling increases glutathione concentrations (Jain and Micinski, 2013; Xu et al., 2015). Here, treatment of monocytes with $1,25(\mathrm{OH})_{2} \mathrm{D}_{3}$ increased $G P X 1$ expression, but the opposite was observed with $25(\mathrm{OH}) \mathrm{D}_{3}$ treatment. We speculate the conflicting results stem from the timing of each metabolite's actions. For instance, $1,25(\mathrm{OH})_{2} \mathrm{D}_{3}$ can act immediately in the cell, whereas $25(\mathrm{OH}) \mathrm{D}_{3}$ must be converted to $1,25(\mathrm{OH}) \mathrm{D}_{3}$ by CYP27B1. Keeping in mind that we measured steady-state transcript abundance at only one time point, it is quite likely the transcript abundance for each gene was not reflective of respective antioxidant activities. Furthermore, posttranslational mechanisms exert substantial control over antioxidant activities of glutathione and thioredoxin systems (Asahi et al., 1995; Rundlöf and Arnér, 2004). Thus, further experiments are needed to assess the effects of vitamin $\mathrm{D}$ on specific antioxidant activities in bovine immunity.

The ability of $25(\mathrm{OH}) \mathrm{D}_{3}$ to support the antioxidant potential of monocytes seemed to depend on stimulation, particularly that of IFN- $\gamma$, indicating that the vitamin D and IFN- $\gamma$ pathways work together to maintain the redox balance of monocytes. For instance, dROM was less in cultures treated with IFN- $\gamma$ and $25(\mathrm{OH}) \mathrm{D}_{3}$ compared with those treated with $25(\mathrm{OH}) \mathrm{D}_{3}$ alone, and upregulation of metallothionein genes depended on IFN- $\gamma$ stimulation. We also observed that, apart from $25(\mathrm{OH}) \mathrm{D}_{3}$, IFN- $\gamma$ was a potent stimulator of metallothionein and thioredoxin genes.

The dependency of $25(\mathrm{OH}) \mathrm{D}_{3}$ effects on antioxidant responses may be explained in part by the transcription factor NFE2L2, a key factor in the activation of cellular antioxidant defenses, including induction of MT1A, MT2A, TRX, and TXNRD1 (Sakurai et al., 2005; Fujie et al., 2016). In our experiments, $25(\mathrm{OH}) \mathrm{D}_{3}$ downregulated expression of NFE2L2 but the effect of $25(\mathrm{OH}) \mathrm{D}_{3}$ on $N F E 2 L 2$ became less pronounced with increasing IFN- $\gamma$. Accordingly, we observed the same pattern of responses for antioxidant potential and metallothionein genes. The interaction between IFN- $\gamma$ and vitamin D also may occur at the point of NFE2L2 protein activity and stability, which we did not measure. To our knowledge, direct binding of the VDR to the metallothionein and thioredoxin promoters in cattle or other species has not been reported. On the other hand, Dai et al. (2019) reported that $1,25(\mathrm{OH})_{2} \mathrm{D}_{3}$ increased antioxidant responses by increasing NFE2L2 translocation to the nucleus. Likewise, Tao et al. (2019) reported that $1,25(\mathrm{OH})_{2} \mathrm{D}_{3}$ decreased NFE2L2 ubiquitination. Those interactions between the VDR and NFE2L2 provide a plausible explanation for how vitamin $\mathrm{D}$ may increase metallothionein and thioredoxin responses despite downregulation of NFE2L2 expression by $25(\mathrm{OH}) \mathrm{D}_{3}$ treatment. Future work should explore the interactions between NFE2L2 and VDR proteins in regulation of antioxidant responses in cattle.

The implications of our findings are significant in understanding the benefits of vitamin D in transition cow health and production. The health benefits that were observed from supplementing prepartum cows 25-hydroxyvitamin $\mathrm{D}_{3}$ (Martinez et al., 2018) may involve increased antioxidant potential of immune cells, in addition to the previously reported antimicrobial actions of vitamin D in bovine immunity (Yue et al., 2017; García-Barragán et al., 2018). In theory, the capacity of vitamin D signaling to increase endogenous antioxidant mechanisms of immune cells will limit the degree of oxidative stress and subsequent tissue damage that occurs from inflammatory insults, such as those of the uterus and mammary glands of postpartum cows that are susceptible to bacterial infections. Consequently, biomarkers for oxidative stress may be key outcomes to assess for the effects of vitamin D treatments in cattle.

\section{References}

Alberti, A., L. Bolognini, D. Macciantelli, and M. Caratelli. 2000. The radical cation of N,N-diethyl-para-paraphenylendiamine: A possible indicator of oxidative stress in biological samples. Res. Chem. Intermed. 26:253-267. https://doi.org/10.1163/156856700X00769.

Asahi, M., J. Fujii, K. Suzuki, H. G. Seo, T. Kuzuya, M. Hori, M. Tada, S. Fujii, and N. Taniguchi. 1995. Inactivation of glutathione peroxidase by nitric oxide. Implication for cytotoxicity. J. Biol. Chem. 270:21035-21039. https://doi.org/10.1074/jbc.270.36.21035.

Crow, J. P. 1997. Dichlorodihydrofluorescein and dihydrorhodamine 123 are sensitive indicators of peroxynitrite in vitro: implications for intracellular measurement of reactive nitrogen and oxygen species. Nitric Oxide 1:145-157. https://doi.org/10.1006/niox.1996.0113.

Dai, Y., J. Zhang, J. Xiang, Y. Li, D. Wu, and J. Xu. 2019. Calcitriol inhibits ROS-NLRP3-IL-1 $\beta$ signaling axis via activation of Nrf2-antioxidant signaling in hyperosmotic stress stimulated human corneal epithelial cells. Redox Biol. 21:101093. https://doi.org/10.1016/j.redox.2018.101093.

Ferret, P. J., E. Soum, O. Negre, E. E. Wollman, and D. Fradelizi. 2000. Protective effect of thioredoxin upon NO-mediated cell injury in THP1 monocytic human cells. Biochem. J. 346:759-765. https://doi.org/10.1042/ bj3460759.

Fujie, T., M. Murakami, E. Yoshida, S. Yasuike, T. Kimura, Y. Fujiwara, C. Yamamoto, and T. Kaji. 2016. Transcriptional induction of metallothionein by tris(pentafluorophenyl)stibane in cultured bovine aortic endothelial cells. Int. J. Mol. Sci. 17:1381. https://doi.org/10.3390/ijms17091381.

García-Barragán, Á., J. A. Gutiérrez-Pabello, and E. Alfonseca-Silva. 2018. Calcitriol increases nitric oxide production and modulates microbicidal capacity against Mycobacterium bovis in bovine macrophages. Comp. Immunol. Microbiol. Infect. Dis. 59:17-23. https://doi.org/10.1016/j.cimid .2018.09.001.

Hewison, M. 2012. Vitamin D and immune function: An overview. Proc. Nutr. Soc. 71:50-61. https://doi.org/10.1017/S0029665111001650.

Holcombe, S. J., L. Wisnieski, J. Gandy, B. Norby, and L. M. Sordillo. 2018. Reduced serum vitamin D concentrations in healthy early-lactation dairy cattle. J. Dairy Sci. 101:1488-1494. https://doi.org/10.3168/jds.2017 -13547 .

Ignarro, L. J., J. M. Fukuto, J. M. Griscavage, N. E. Rogers, and R. E. Byrns. 1993. Oxidation of nitric oxide in aqueous solution to nitrite but not nitrate: comparison with enzymatically formed nitric oxide from L-arginine. Proc. Natl. Acad. Sci. USA 90:8103-8107. https://doi.org/10.1073/pnas.90.17 .8103 .

Itoh, N., H. Shibayama, M. Kanekiyo, D. Namphung, T. Nakanishi, A. Matsuyama, T. Odani, and K. Tanaka. 2005. Reduced bactericidal activity and nitric oxide production in metallothionein-deficient macrophages in re- 
sponse to lipopolysaccharide stimulation. Toxicology 216:188-196. https:/ /doi.org/10.1016/j.tox.2005.08.005.

Jain, S. K., and D. Micinski. 2013. Vitamin D upregulates glutamate cysteine ligase and glutathione reductase, and GSH formation, and decreases ROS and MCP-1 and IL-8 secretion in high-glucose exposed U937 monocytes. Biochem. Biophys. Res. Commun. 437:7-11. https://doi.org/10.1016/j .bbrc.2013.06.004.

Kweh, M. F., K. E. Merriman, and C. D. Nelson. 2019. Short communication Inhibition of DNA methyltransferase and histone deacetylase increases $\beta$-defensin expression but not the effects of lipopolysaccharide or 1,25-dihydroxyvitamin D. J. Dairy Sci. 102:5706-5712. https://doi.org/10.3168/ jds.2018-16141.

Lippolis, J. D., T. A. Reinhardt, R. A. Sacco, B. J. Nonnecke, and C. D. Nelson. 2011. Treatment of an intramammary bacterial infection with 25-hydroxyvitamin D(3). PLoS One 6:e25479. https://doi.org/10.1371/journal pone. 0025479 .

Martinez, N., R. M. Rodney, E. Block, L. L. Hernandez, C. D. Nelson, I. J. Lean, and J. E. P. Santos. 2018. Effects of prepartum dietary cation-anion difference and source of vitamin $\mathrm{D}$ in dairy cows: Health and reproductive responses. J. Dairy Sci. 101:2563-2578. https://doi.org/10.3168/jds.2017 -13740 .

Merriman, K. E., M. F. Kweh, J. L. Powell, J. D. Lippolis, and C. D. Nelson, 2015. Multiple $\beta$-defensin genes are upregulated by the vitamin D pathway in cattle. J. Steroid Biochem. Mol. Biol. 154:120-129. https://doi.org/10 $.1016 /$ j.jsbmb.2015.08.002.

Merriman, K. E., M. B. Poindexter, M. F. Kweh, J. E. Santos, and C. D. Nelson. 2017. Intramammary 1,25-dihydroxyvitamin $\mathrm{D}_{3}$ treatment increases expression of host-defense genes in mammary immune cells of lactating dairy cattle. J. Steroid Biochem. Mol. Biol. 173:33-41. https://doi.org/10 $.1016 / \mathrm{j} . j \mathrm{jsbmb} .2017 .02 .006$.

Merriman, K. E., J. L. Powell, J. E. P. Santos, and C. D. Nelson. 2018. Intramammary 25-hydroxyvitamin D3 treatment modulates innate immune responses to endotoxin-induced mastitis. J. Dairy Sci. 101:7593-7607. https://doi.org/10.3168/jds.2017-14143.

Nelson, C. D., J. D. Lippolis, T. A. Reinhardt, R. E. Sacco, J. L. Powell, M. E. Drewnoski, M. O'Neil, D. C. Beitz, and W. P. Weiss. 2016. Vitamin D status of dairy cattle: Outcomes of current practices in the dairy industry. J. Dairy Sci. 99:10150-10160. https://doi.org/10.3168/jds.2016-11727.

Nelson, C. D., T. A. Reinhardt, T. C. Thacker, D. C. Beitz, and J. D. Lippolis. 2010. Modulation of the bovine innate immune response by production of 1alpha,25-dihydroxyvitamin D(3) in bovine monocytes. J. Dairy Sci. 93:1041-1049. https://doi.org/10.3168/jds.2009-2663.

Poindexter, M. B., M. F. Kweh, R. Zimpel, J. Zuniga, C. Lopera, M. G. Zenobi, Y. Jiang, M. Engstrom, P. Celi, J. E. P. Santos, and C. D. Nelson. 2020. Feeding supplemental 25-hydroxyvitamin $\mathrm{D}_{3}$ increases serum mineral concentrations and alters mammary immunity of lactating dairy cows. J. Dairy Sci. 103:805-822. https://doi.org/10.3168/jds.2019-16999.

Rundlöf, A. K., and E. S. Arnér. 2004. Regulation of the mammalian selenoprotein thioredoxin reductase 1 in relation to cellular phenotype, growth, and signaling events. Antioxid. Redox Signal. 6:41-52. https://doi.org/10 $.1089 / 152308604771978336$.

Sakurai, A., M. Nishimoto, S. Himeno, N. Imura, M. Tsujimoto, M. Kunimoto, and S. Hara. 2005. Transcriptional regulation of thioredoxin reductase 1 expression by cadmium in vascular endothelial cells: Role of NF-E2related factor-2. J. Cell. Physiol. 203:529-537. https://doi.org/10.1002/jcp .20246 .
Schütze, N., J. Fritsche, R. Ebert-Dümig, D. Schneider, J. Köhrle, R. Andreesen, M. Kreutz, and F. Jakob. 1999. The selenoprotein thioredoxin reductase is expressed in peripheral blood monocytes and THP1 human myeloid leukemia cells-Regulation by 1,25-dihydroxyvitamin D3 and selenite. Biofactors 10:329-338. https://doi.org/10.1002/biof.5520100403.

Schwarz, M. A., J. S. Lazo, J. C. Yalowich, W. P. Allen, M. Whitmore, H. A Bergonia, E. Tzeng, T. R. Billiar, P. D. Robbins, and J. R. Lancaster. 1995. Metallothionein protects against the cytotoxic and DNA-damaging effects of nitric oxide. Proc. Natl. Acad. Sci. USA 92:4452-4456. https://doi.org/ 10.1073/pnas.92.10.4452.

Shi, H. Y., S. M. Yan, Y. M. Guo, B. Q. Zhang, X. Y. Guo, and B. L. Shi. 2018. Vitamin A pretreatment protects NO-induced bovine mammary epithelial cells from oxidative stress by modulating Nrf2 and NF- $\mathrm{kB}$ signaling pathways. J. Anim. Sci. 96:1305-1316. https://doi.org/10.1093/jas/sky037.

Sordillo, L. M. 2016. Nutritional strategies to optimize dairy cattle immunity. J. Dairy Sci. 99:4967-4982. https://doi.org/10.3168/jds.2015-10354.

Tao, S., H. Zhang, L. Xue, X. Jiang, H. Wang, B. Li, H. Tian, and Z. Zhang. 2019. Vitamin D protects against particles-caused lung injury through induction of autophagy in an Nrf2-dependent manner. Environ. Toxicol. 34:594-609. https://doi.org/10.1002/tox.22726.

Trigona, W. L., I. K. Mullarky, Y. Cao, and L. M. Sordillo. 2006. Thioredoxin reductase regulates the induction of haem oxygenase-1 expression in aortic endothelial cells. Biochem. J. 394:207-216. https://doi.org/10.1042/ BJ20050712.

Virág, L., R. I. Jaén, Z. Regdon, L. Boscá, and P. Prieto. 2019. Self-defense of macrophages against oxidative injury: Fighting for their own survival. Redox Biol. 26:101261. https://doi.org/10.1016/j.redox.2019.101261.

Weiss, G., and U. E. Schaible. 2015. Macrophage defense mechanisms against intracellular bacteria. Immunol. Rev. 264:182-203. https://doi.org/10 .1111/imr.12266.

Wisnieski, L., J. L. Brown, S. J. Holcombe, J. C. Gandy, and L. M. Sordillo. 2020. Serum vitamin D concentrations at dry-off and close-up predict increased postpartum urine ketone concentrations in dairy cattle. J. Dairy Sci. 103:1795-1806. https://doi.org/10.3168/jds.2019-16599.

Xu, S., Y. H. Chen, Z. X. Tan, D. D. Xie, C. Zhang, M. Z. Xia, H. Wang, H. Zhao, D. X. Xu, and D. X. Yu. 2015. Vitamin D3 pretreatment alleviates renal oxidative stress in lipopolysaccharide-induced acute kidney injury. J. Steroid Biochem. Mol. Biol. 152:133-141. https://doi.org/10.1016/j.jsbmb 2015.05.009.

Yue, Y., L. Hymøller, S. K. Jensen, C. Lauridsen, and S. Purup. 2017. Effects of vitamin D and its metabolites on cell viability and Staphylococcus aureus invasion into bovine mammary epithelial cells. Vet. Microbiol. 203:245-251. https://doi.org/10.1016/j.vetmic.2017.03.008.

\section{Notes}

Corwin D. Nelson @ https://orcid.org/0000-0003-0195-5610

This work was supported with funds from USDA Hatch Project FLAANS-005309 through the University of Florida Institute of Food and Agricultural Sciences and funds from the Southeast Milk Inc. Milk Checkoff Research and Promotion Board (Belleview, FL).

The authors thank Madelin Pozadas, Gabriela Silva, and Danna Burgos Vera at the University of Florida for their technical assistance.

The authors have not stated any conflicts of interest. 